\title{
Transforming growth factor $\beta_{1}$ inhibits bone morphogenic protein (BMP)-2 and BMP-7 signaling via upregulation of Ski-related novel protein $\mathrm{N}(\mathrm{SnoN})$ : possible mechanism for the failure of BMP therapy?
}

Sabrina Ehnert ${ }^{1 *+}$, Jian Zhao ${ }^{2+}$, Stefan Pscherer ${ }^{3}$, Thomas Freude $^{1}$, Steven Dooley ${ }^{4}$, Andreas Kolk ${ }^{5}$, Ulrich Stöckle ${ }^{1}$, Andreas Klaus Nussler ${ }^{1,2+}$ and Robert Hube ${ }^{6+}$

\begin{abstract}
Background: Bone morphogenic proteins (BMPs) play a key role in bone formation. Consequently, it was expected that topical application of recombinant human (rh)BMP-2 and rhBMP-7 would improve the healing of complex fractures. However, up to $36 \%$ of fracture patients do not respond to this therapy. There are hints that a systemic increase in transforming growth factor $\beta_{1}\left(T G F \beta_{1}\right)$ interferes with beneficial BMP effects. Therefore, in the present work we investigated the influence of rhTGF $\beta_{1}$ on rhBMP signaling in primary human osteoblasts, with the aim of more specifically delineating the underlying regulatory mechanisms.

Methods: BMP signaling was detected by adenoviral Smad-binding-element-reporter assays. Gene expression was determined by reverse transcription polymerase chain reaction (RT-PCR) and confirmed at the protein level by western blot. Histone deacetylase (HDAC) activity was determined using a test kit. Data sets were compared by one-way analysis of variance.

Results: Our findings showed that Smad1/5/8-mediated rhBMP-2 and rhBMP-7 signaling is completely blocked by rhTGF $\beta_{1}$. We then investigated expression levels of genes involved in BMP signaling and regulation (for example, Smad1/5/8, TGF $\beta$ receptors type I and II, noggin, sclerostin, BMP and activin receptor membrane bound inhibitor (BAMBI), v-ski sarcoma viral oncogene homolog (Ski), Ski-related novel protein N (SnoN) and Smad ubiquitination regulatory factors (Smurfs)) and confirmed the expression of regulated genes at the protein level. Smad7 and SnoN were significantly induced by rhTGF $\beta_{1}$ treatment while expression of Smad1, Smad6, TGF $\beta$ RII and activin receptorlike kinase 1 (Alk1) was reduced. Elevated SnoN expression was accompanied by increased HDAC activity. Addition of an HDAC inhibitor, namely valproic acid, fully abolished the inhibitory effect of rhTGF $\beta_{1}$ on rhBMP-2 and rhBMP7 signaling.

Conclusions: rhTGF $\beta 1$ effectively blocks rhBMP signaling in osteoblasts. As possible mechanism, we postulate an induction of SnoN that increases HDAC activity and thereby reduces the expression of factors required for efficient BMP signaling. Thus, inhibition of HDAC activity may support bone healing during rhBMP therapy in patients with elevated TGF $\beta$ serum levels.
\end{abstract}

Keywords: alkaline phosphatase, mineralized matrix, osteoblasts, rhBMPs, TGF $\beta$

\footnotetext{
* Correspondence: sehnert@bgu-tuebingen.de

† Contributed equally

'BG Trauma Center, Eberhard Karls Universität Tübingen, Schnarrenbergstr.

95, D-72076, Tübingen, Germany

Full list of author information is available at the end of the article
} 


\section{Background}

In order to maintain a constant bone mass in the adult skeleton, bone remodeling underlies a coordinated process of bone formation and bone resorption. While bone is formed by osteoblasts, which are of mesenchymal origin, it is resorbed by osteoclasts that are derived from the hematopoietic system. An imbalance in this process may cause pathological loss of bone mass as seen with delayed fracture healing, osteoporosis and other metabolic bone diseases.

Bone morphogenic proteins (BMPs) promote osteogenesis, chondrogenesis and adipogenesis of mesenchymal progenitor cells [1]. The biological activity of recombinant human (rh)BMPs (2, 4 and 7) has been defined by using a variety of animal models. For example, when implanted with a suitable matrix, these rhBMPs have been shown to enhance allograft incorporation and induce new bone formation at various skeletal sites. Clinical trials using rhBMPs were successful in the treatment of open tibial fractures, distal tibial fractures, tibial non-unions, scaphoid non-unions and atrophic long bone non-unions [2-7]. Despite these proven positive effects of BMPs on bone healing, the universal use of rhBMPs is tempered by high costs, lingering safety concerns (for example, vertebral osteolysis, ectopic bone formation, radiculitis or cervical soft tissue swelling), and a relatively high failure rate with up to $36 \%$ of patients not responding to this therapy $[8,9]$. There are hints that a systemic increase in transforming growth factor $\beta$ (TGF $\beta$ ) is at least partially responsible for this therapy resistance, as it causes BMP signaling interference [10]. Therefore, in order to design an improved second-generation therapy, it is necessary to fully understand the molecular mechanisms of the activity of rhBMPs in the setting of bone defect therapy.

TGF $\beta$, with its three isoforms $\left(\beta_{1}, \beta_{2}\right.$ and $\left.\beta_{3}\right)$, is by far the most abundant cytokine in bone. All three isoforms are secreted in their latent form within bone matrix, waiting to be activated by osteoclasts during bone turnover in order to recruit osteoblast progenitor cells, and thereby stimulating bone formation [11]. BMPs belong to the TGF $\beta$ superfamily, where all members transduce their signals through two types of serine/threonine kinase receptors, termed type I and type II [12]. The type II receptors are constitutively active kinases that phosphorylate type I receptors upon ligand binding. Seven type I receptors, termed activin receptor-like kinase (Alk)1 to Alk7, have been identified in mammals. BMPs, activins and TGF $\beta_{1-3}$ bind different type I receptors. This binding is cell type dependent: BMPs preferably bind Alk1, Alk2, Alk3 and Alk6, whereas activins and TGF $\beta_{1-3}$ bind Alk4 and Alk5, respectively. Upon activation by the type II receptor, Alks activate (phosphorylate) Smad transcription factors in the cytoplasm. To date, eight different Smads have been identified in mammals that are classified into three groups: receptor-regulated Smads (R-Smads/Smad1, Smad2, Smad3, Smad5 and Smad8), inhibitory Smads (I-Smads/ Smad6 and Smad7) and the common-partner Smad (coSmad/Smad4). In osteoblasts BMPs preferably activate Smad1/5/8 while TGF $\beta_{1-3}$ activate Smad2/3 [12]. Upon activation, Smads $1 / 5 / 8$ and Smads $2 / 3$ form complexes with Smad4, which provides transcription factor activity, regulating target gene expression in the nucleus [12] including genes participating in feedback mechanisms of the signaling pathway itself. Besides I-Smads, these genes include Smad ubiquitination regulatory factor (Smurf) 1 and Smurf2, Smad anchor for receptor activation (SARA), BMP and activin receptor membrane bound inhibitor (BAMBI), v-ski sarcoma viral oncogene homolog (Ski), Ski-related novel protein $\mathrm{N}(\mathrm{SnoN})$, sclerostin and noggin. While Smad6 specifically interferes with the Smad1/5/8 pathway, Smad7 is able to blunt both Smad1/5/8-mediated as well as Smad2/3-mediated signal transduction. Mechanistically, I-Smads interact with TGF $\beta$ family receptors and Smad proteins in order to facilitate their ubiquitination and degradation with the help of the E3 ubiquitin ligases Smurf1 and Smurf2 [12]. SARA, known as a Smad cofactor, directly interacts with $\operatorname{Smad} 2$ and favors its recruitment to the TGF $\beta$ receptor, thereby enhancing TGF $\beta$ signaling [12]. BAMBI has structural features of a decoy receptor and inhibits TGF $\beta / B M P$ signaling (receptor activation) by competing with the type I receptor for ligand binding [12]. Ski and SnoN belong to the negative regulators of Smad transcriptional function, antagonizing TGF $\beta$ signaling primarily through transcriptional modulation via recruitment of nuclear transcriptional corepressor and histone deacetylase (HDAC) [12]. Sclerostin regulates bone mass by competing with BMP for receptor binding [13]. In an earlier study, we demonstrated that TGF $\beta_{1}$ inhibits rhBMP-2 and rhBMP-7 signaling in primary human osteoblasts [14]. This finding is of particular interest, as patients with various inflammatory reactions, for example, liver fibrosis or cirrhosis, cardiac fibrosis, chronic renal failure or fibrosis of other tissues, have constantly increased active TGF $\beta_{1}$ serum levels $[15,16]$. Distribution of the excessively produced TGF $\beta$ through the body via the bloodstream may significantly influence the biological activity of rhBMPs at fracture sites. Therefore, the aim of this study was to identify the molecular details of the mechanism by which rhTGF $\beta_{1}$ inhibits rhBMP-2 and rhBMP-7 signaling in primary human osteoblasts, in order to identify possible therapeutic targets to resensitize patients with chronically increased TGF $\beta_{1}$ serum levels to BMP therapy.

\section{Methods}

Human recombinant (rh)TGF $\beta 1$, rhBMP-2 and rhBMP-7 were from Peprotech (London, UK); cell culture medium 
and supplements were from PAA (Cölbe, Germany); primary and secondary antibodies were from Santa Cruz Biotechnology (Heidelberg, Germany) and Cell Signaling (Frankfurt am Main, Germany); chemicals were from Sigma (Munich, Germany).

\section{Isolation and culture of primary human osteoblasts}

Osteoblasts were isolated from femur heads of patients undergoing total hip replacement, in accordance with the ethical code of the 'Klinikum rechts der Isar' (MRI, Technische Universität München, Germany) and the patients' written consent. Briefly, cancellous bone was removed mechanically from the femur head and washed three to five times with Dulbecco's phosphate buffered saline (DPBS). After $1 \mathrm{~h}$ of collagenase digestion (DPBS, 0.07\% collagenase II; Biochrom AG, Berlin, Germany) at $37^{\circ} \mathrm{C}$, cancellous bone was washed with DPBS and released osteoblast cells were transferred to cell culture flasks in culture medium (minimal essential medium (MEM)/ Ham's F12, 10\% fetal calf serum (FCS), $2 \mathrm{mM} \mathrm{L}$-glutamine, $100 \mathrm{U} / \mathrm{ml}$ penicillin, $100 \mu \mathrm{g} / \mathrm{ml}$ streptomycin, $50 \mu \mathrm{M}$ L-ascorbate-2-phosphate, $50 \mu \mathrm{M} \beta$-glycerol phosphate) for expansion. Medium was changed every 4 to 5 days. Experiments were performed in passages 3 and 4, when a pure population of osteoblasts was reached (negative for CD14 and CD45 and positive for CD90 and CD105), as determined by flow cytometry [14].

\section{Transient cell infections and reporter gene assay}

Cells were infected with $S$ mad1/5/8 reporter adenovirus particles (Ad5-BRE-Luc, provided by Dr O Korchynskyi and Professor P ten Dijke (Leids Universitair Medisch Centrum, Leiden, Netherlands) as described previously [14]. Upon binding of phosphorylated Smad1/5/8/4 to the plasmid, luciferase is expressed by the cells. Cell lysate preparation and luciferase measurement were performed according to the manufacturer's instructions, using the Steady-Glo Luciferase Assay System (Promega, Madison, WI, USA) and normalized to total protein content. Infection efficiency was $>90 \%$, as shown by fluorescent microscopy of cells infected with Ad5-green fluorescent protein (GFP) particles $(24 \mathrm{~h})$.

\section{Conventional reverse transcription polymerase chain reaction (RT-PCR)}

Total cellular RNA was isolated using Trifast (Peqlab, Erlangen, Germany) according to the manufacturer's protocol. First-strand cDNA was synthesized from $1 \mu \mathrm{g}$ total RNA using the First Strand cDNA Synthesis Kit from Fermentas (St. Leon-Rot, Germany). Primer information is summarized in Table 1. Products, resolved by gel electrophoresis in a $1.8 \%(\mathrm{w} / \mathrm{v})$ agarose gel, were visualized with ethidium bromide. Densitometric analysis of signals was performed using the Image J software (NIH, Bethesda, MD, USA).

\section{Western blot}

Cells were lysed in ice-cold radioimmunoprecipitation assay (RIPA) lysis buffer (50 mM Tris; $250 \mathrm{mM} \mathrm{NaCl} ; 2 \%$ Nonidet-P40; $2.5 \mathrm{mM}$ ethylenediaminetetra-acetic acid (EDTA); 0.1\% SDS; 0.5\% deoxycholate; complete mini protease inhibitor and phosphatase inhibitor according to the manufacturer's instructions; $\mathrm{pH}=7.2$ ). Protein concentration was determined by micro-Lowry process [17]. A total of $30 \mu \mathrm{g}$ protein was separated by SDS-PAGE and transferred to nitrocellulose membranes (Roth, Karlsruhe, Germany). After overnight incubation with primary antibodies (1:1,000 in Tris-buffered saline/Tween 20 (TBST)) at $4^{\circ} \mathrm{C}$, membranes were incubated with the corresponding horseradish peroxidase-labeled secondary antibodies for $2 \mathrm{~h}$ at room temperature. Chemiluminescent signals were detected on $\mathrm{x}$-ray films.

\section{HDAC activity measurement}

HDAC activity was determined in living cells using the SensoLyte ${ }^{\mathrm{TM}}$ HDAC Activity Fluorometric Assay Kit (AnaSpec, Fremont, CA, USA).

\section{Statistics}

Results are expressed as mean \pm SEM of at least three independent experiments $(\mathrm{N} \geq 3)$ measured as triplicates or more $(n \geq 3)$. Data sets were compared by one-way analysis of variance followed by Bonferroni's multiple comparison test (GraphPad Prism Software, El Camino Real, CA, USA). $P<0.05$ was taken as minimum level of significance.

\section{Results}

rhTGF $\beta_{1}$ blocks rhBMP-2-mediated and rhBMP-7-mediated Smad1/5/8 signaling in human osteoblasts

Primary human osteoblasts $(\mathrm{N}=4)$ were infected with Ad5-BRE-Luc adenoviral particles (Smad1/5/8 reporter construct) and stimulated for 24, 48, 72 and $96 \mathrm{~h}$ with 50 $\mathrm{ng} / \mathrm{ml}$ of rhBMP-2 or rhBMP-7. Luciferase activity was measured in cell lysates $(n=6)$. The highest luciferase signal was observed after $72 \mathrm{~h}$ (Figure 1A). Therefore, we repeated the experiment $(72 \mathrm{~h}$ stimulation with $50 \mathrm{ng} / \mathrm{ml}$ rhBMP-2 or rhBMP-7) in the presence or absence of $5 \mathrm{ng} /$ $\mathrm{ml}$ rhTGF $\beta_{1}$. Again, rhBMP-2 and rhBMP-7 induced Smad1/5/8 signaling in primary human osteoblasts. However, addition of rhTGF $\beta_{1}$ completely blocked rhBMP-2mediated and rhBMP-7-mediated Smad1/5/8 signaling (Figure 1B). Stimulation with $\mathrm{rhTGF} \beta_{1}$ itself did not induce Smad1/5/8 signaling in primary human osteoblasts [14]. 
Table 1 Summary of polymerase chain reaction (PCR) conditions

\begin{tabular}{|c|c|c|c|c|c|}
\hline Gene & GeneBank accession no. [NM_] & Forward primer $5^{\prime}-3^{\prime}$ & Reverse primer $5^{\prime}-3^{\prime}$ & $\operatorname{Tm}\left({ }^{\circ} \mathrm{C}\right)$ & Product length (bp) \\
\hline$\overline{A l k 1}$ & NM_000020.1 & GCTCAGACACGACAACATCC & ATTGCGGCTCTTGAAGTCG & 60 & 256 \\
\hline Alk2 & NM_001616.2 & CTTGCATTGCTGACTTTGG & CCAATTTCCTCCTCAAATGG & 60 & 253 \\
\hline Alk3 & NM_004329 & CACTGCCCCCTGTTGTCATAG & ATCCTGTTCCAAATCACGATTGT & 58 & 179 \\
\hline Alk5 & NM_004612.1 & TGTTGGTACCCAAGGAAAGC & AACATCGTCGAGCAATTTCC & 60 & 287 \\
\hline Alk6 & NM_001203 & CTITTGCGAAGTCAGGAAAAT & TGTTGACTGAGTCTTCTGGACAA & 56 & 130 \\
\hline TGF $\beta R \|$ & NM_3242.3 & ATGCTGCTTCTCCAAAGTGC & AGGTTGAACTCACGTTCTGC & 57 & 258 \\
\hline Smad1 & NM_005900.1 & CAACGGAGTAACTGTGTCACC & ATTCGCTGTGTCTTGGAACC & 60 & 259 \\
\hline Smad2 & NM_00100365 & CAAACCAGGTCTCTTGATGG & GAGGCGGAAGTTCTGTTAGG & 60 & 259 \\
\hline Smad3 & NM_005902.2 & GGAGAAATGGTGCGAGAAGG & GAAGGCGAACTCACACAGC & 60 & 258 \\
\hline Smad4 & NM_005359.3 & TGAATCCATATCACTACGAAC & CAGGCTGACTTGTGGAAG & 60 & 294 \\
\hline Smad5 & NM_005903.5 & AACCTGAGCCACAAGAAC & GGCTGGGAATTATCTTGACC & 60 & 245 \\
\hline Smad6 & NM_U59914 & GGCAAACCCATAGAGACACAA & GGTAGCCTCCGTTTCAGTGTA & 56 & 123 \\
\hline Smad7 & NM_005904.1 & TTCGGACAACAAGAGTCAGC & AAGCCTTGATGGAGAAACC & 60 & 201 \\
\hline Smurf1 & NM_020429.1 & CAGCATCAAGATCCGTCTGA & GCATAGATCCAAACGCTGGT & 58 & 325 \\
\hline Smurf2 & NM_022739.3 & AGACTGGTGTGAGCACATGG & СACTTGCTGTTGCTGTTGGT & 58 & 239 \\
\hline SARA & NM_007324.2 & TGGTTTGCTGATGGGATCTT & TTCCAACAGGACTTCCAACC & 58 & 196 \\
\hline $\mathrm{BAMBI}$ & NM_012342.2 & GGATCGCCACTCCAGCTAC & TGGTGTCCGTGAAAGCTGTA & 58 & 603 \\
\hline Ski & NM_003036.3 & TCCGCGTGTACCACGAGTGC & AGCAGGATGTAGGCCCGCCA & 60 & 208 \\
\hline SnoN & NM_005414.3 & GCCACGAACTTTTCCTCAAA & GCTGGGGTGTAAAAATGAATG & 58 & 493 \\
\hline Noggin & NM_005450.4 & CAGCGACAACCTGCCCCTGG & GATCTCGCTCGGCATGGCCC & 56 & 249 \\
\hline Sclerostin & NM_025237.2 & CAGCTGCCGCGAGCTGCACT & GCACTTGCACGAGGCCACCA & 62 & 248 \\
\hline$\beta$-Actin & NM_001101.3 & CGACAACGGCTCCGGCATGT & GCACAGTGTGGGTGACCCCG & 64 & 461 \\
\hline
\end{tabular}

Alk = activin receptor-like kinase; BAMBI = bone morphogenic protein and activin receptor membrane bound inhibitor; SARA = Smad anchor for receptor activation; Ski = v-ski sarcoma viral oncogene homolog; Smurf = Smad ubiquitination regulatory factors; SnoN = Ski-related novel protein N; TGF $\beta$ RII = transforming growth factor $\beta$ receptor II.

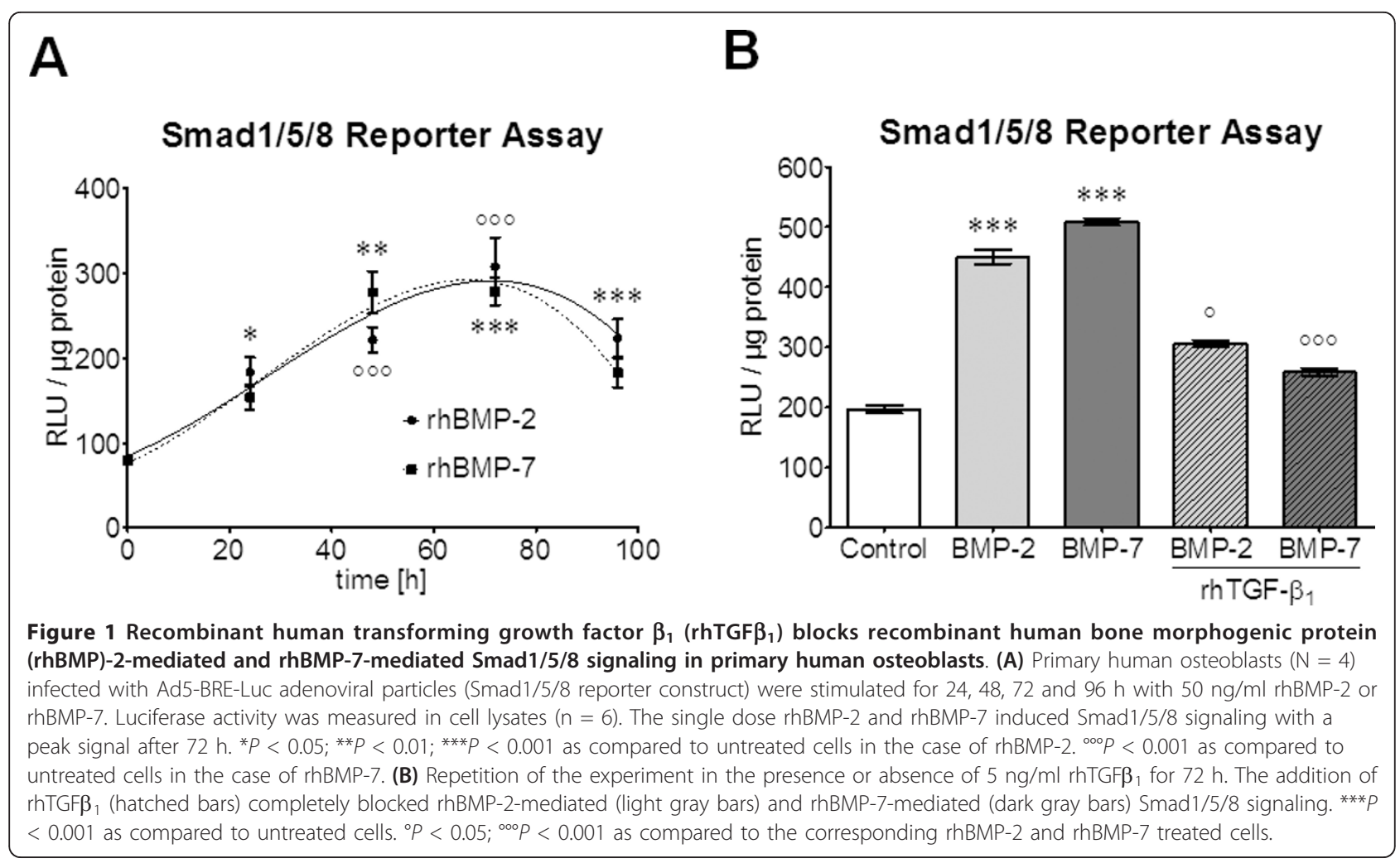


rhTGF $\beta_{1}$ reduces Smad1, Smad6, TGF $\beta$ Rs and BAMBI expression but induces Smad7 and SnoN expression in human osteoblasts

Primary human osteoblasts $(\mathrm{N}=3)$ were treated with 50 $\mathrm{ng} / \mathrm{ml}$ of rhBMP-2 or rhBMP-7 in the presence or absence of $5 \mathrm{ng} / \mathrm{ml} \mathrm{rhTGF} \beta_{1}$. After $72 \mathrm{~h}, \mathrm{mRNA}$ was isolated for expression analysis. RT-PCR experiments were performed for the transcription factors Smad1-7, the receptors Alk13, Alk5, Alk6 and TGF $\beta$ RII as well as for the regulatory elements Smurf1, Smurf2, SARA, BAMBI, Ski, SnoN, noggin and sclerostin. $\beta$-Actin was used as housekeeping gene. Densitometric analysis $(n=6)$ showed that mRNA levels of Smad1, Smad6 and TGF $\beta$ receptors I (Alk1) and II were strongly downregulated upon stimulation with rhTGF $\beta_{1}$ (Figure 2A-D). Similarly, BAMBI showed a tendency to be downregulated by $\operatorname{rhTGF} \beta_{1}$. At the contrary, mRNA levels of the Smad7 and SnoN were significantly upregulated by rhTGF $\beta_{1}$ (Figure 2E, F). All the other genes investigated were not significantly changed by rhBMP-2, rhBMP-7 or rhTGF $\beta_{1}$.

\section{Protein levels of Smad1 and TGF $\beta$ R were reduced, whereas SnoN was increased by $\operatorname{rhTGF} \beta_{1}$ in human osteoblasts}

Primary human osteoblasts $(\mathrm{N}=7)$ were treated with 50 $\mathrm{ng} / \mathrm{ml}$ rhBMP-2 or rhBMP-7 in the presence or absence of $5 \mathrm{ng} / \mathrm{ml} \mathrm{rhTGF} \beta_{1}$. After $72 \mathrm{~h}$ cells were lysed for western blot analysis. Membranes were probed for Smad1/2, phospho-Smad1/5/8, TGF $\beta$ R and SnoN. Glyceraldehyde 3phosphate dehydrogenase (GAPDH) was used as loading control (Figure 3A). Densitometric analysis $(n=6)$ confirmed reduced Smad1/5/8 phosphorylation (Figure 3B), downregulation of Smad1 and TGF $\beta$ R (Figure 3C, D) as well as upregulation of SnoN (Figure 3E) by rhTGF $\beta_{1}$ at the protein level. Expression of Smad2 was not significantly changed by the different treatments.

\section{The BMP-2/BMP-7 antagonizing effect of $\operatorname{rhTGF} \beta_{1}$ in primary human osteoblasts is mediated via induction of HDAC activity}

Treatment of primary human osteoblasts $(\mathrm{N}=4, \mathrm{n}=3)$ with $5 \mathrm{ng} / \mathrm{ml} \mathrm{rhTGF} \beta_{1}$ for $72 \mathrm{~h}$ significantly induced HDAC activity. Two subtoxic doses $(100 \mu \mathrm{M}$ and 200 $\mu \mathrm{M})$ of the HDAC inhibitor valproic acid effectively inhibited HDAC activity in our system (Figure 4A). In order to investigate whether the BMP-2/BMP-7 antagonizing effect of rhTGF $\beta_{1}$ is dependent on the increased HDAC activity, we repeated the $S$ mad $1 / 5 / 8$ reporter assay in the presence or absence of the HDAC inhibitor. Therefore, Ad5-BRE-Luc infected osteoblasts were coincubated with $100 / 200 \mu \mathrm{M}$ valproic acid and $50 \mathrm{ng} / \mathrm{ml}$ rhBMP-2 or rhBMP-7 in the presence or absence of 5 $\mathrm{ng} / \mathrm{ml} \mathrm{rhTGF} \beta_{1}$. Valproic acid effectively countered the BMP-2/BMP-7 antagonizing effect of $\operatorname{rhTGF} \beta_{1}$, as measured by luciferase activity in cell lysates. Interestingly, Smad1/5/8 signaling induced by rhBMP-2 and rhBMP-7 in the setting of HDAC inhibition even reached luciferase activity levels above those obtained by rhBMP-2 and rhBMP-7 alone (Figure 4B).

\section{Protein levels of Smad1, Smad2 and TGF $\beta$ R were not affected by valproic acid treatment}

Primary human osteoblasts $(\mathrm{N}=3)$ were treated with 50 $\mathrm{ng} / \mathrm{ml}$ rhBMP-2 or rhBMP-7 or $100 / 200 \mu \mathrm{M}$ valproic acid in the presence or absence of $5 \mathrm{ng} / \mathrm{ml} \mathrm{rhTGF} \beta_{1}$. After $72 \mathrm{~h}$ cells were lysed for western blot analysis. Membranes were probed for Smad1, Smad2, phosphoSmad1/5/8, and TGF $\beta$ R. GAPDH was used as loading control (Figure 5A). Densitometric analysis $(n=6)$ showed, besides reduced $S \operatorname{mad} 1 / 5 / 8$ phosphorylation and downregulation of Smad1 and TGF $\beta$ R by rhTGF $\beta_{1}$, that protein levels were not significantly affected by treatment with valproic acid (Figure 5B-D).

\section{Discussion}

TGF $\beta$ is secreted by bone cells. Therefore, bone represents one of the biggest reservoirs for all three TGF $\beta$ isoforms $\left(\beta_{1}, \beta_{2}\right.$ and $\left.\beta_{3}\right)$ in the human body. In bone matrix, the TGF $\beta$ isoforms are present in their latent form, which become activated upon need (for example, during bone resorption by osteoclasts). The relevance of TGF $\beta$ for bone formation physiology is underlined by the finding that TGF $\beta_{1}$ knockout mice have a decreased tibia length of about $30 \%$ and a reduced bone mineral content [18]. Furthermore, local injection of TGF $\beta_{1}$ under the periosteum stimulates the formation of cartilage and bone $[19,20]$ and systemic application of TGF $\beta_{2}$ leads to a general increase in osteoblast activity [21]. In contrast, transgenic mice with continuous overexpression of TGF $\beta_{2}$ in osteoblasts show a dramatic, age-dependent loss of bone mass [22]. Along the same lines, transgenic mice lacking functional TGF $\beta$ signaling in osteoblasts [23] or mice treated with the TGF $\beta$ type I receptor kinase inhibitor SD-208 [24] have increased trabecular bone mass with tougher femurs and stiffer and stronger vertebral bodies. Contrary to earlier findings, these data suggest that continuous exposure to active TGF $\beta$ might harm bone physiology, as can be seen in patients suffering from chronic inflammation, whose active TGF $\beta_{1}$ serum levels are often constantly increased. In an earlier work, we showed that continuously elevated rhTGF $\beta_{1}$ levels inhibit osteoblast function, for example, alkaline phosphatase (AP) activity and formation of mineralized matrix. One possible mechanism by which TGF $\beta_{1}$ may exert its inhibitory effect on osteoblast differentiation is interfering with BMP signaling [14]. Therefore, the aim of this study was to investigate possible regulatory mechanisms by which rhTGF $\beta_{1}$ inhibits rhBMP-2 and 


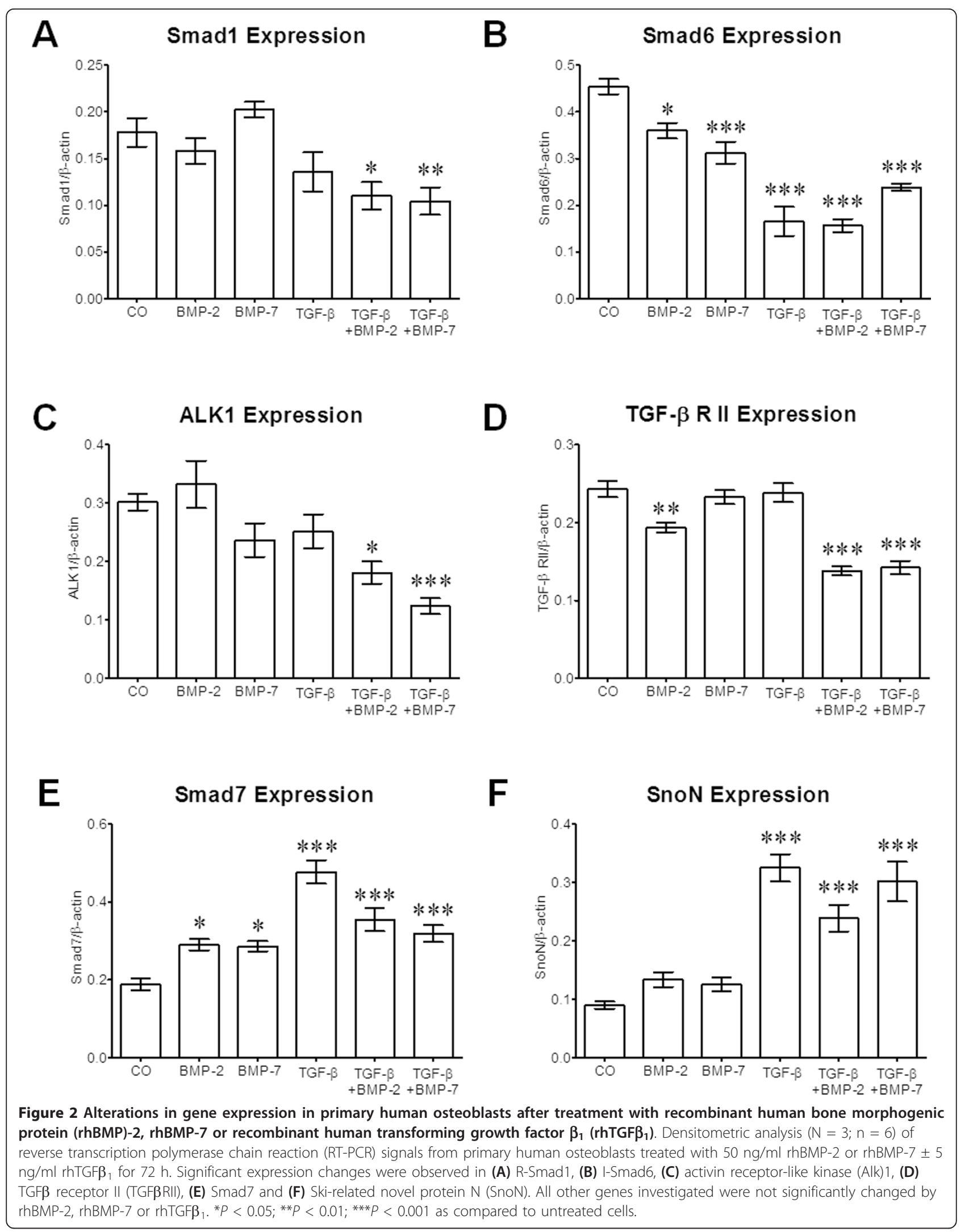




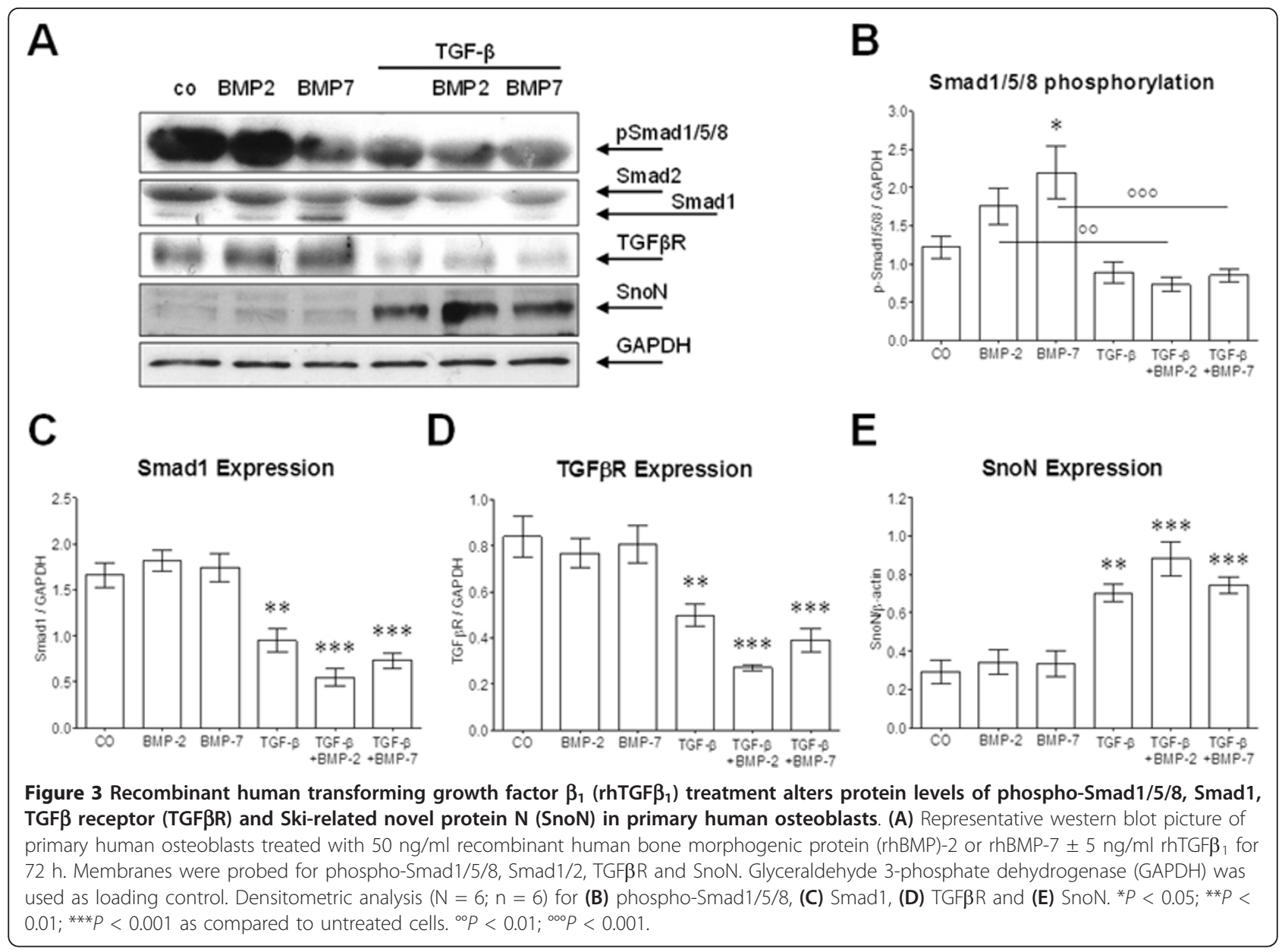

rhBMP-7 signaling in primary human osteoblasts. We demonstrated that rhBMP-2 and rhBMP-7 induce Smad1/5/8 signaling primary osteoblasts, isolated from femoral heads of patients undergoing total hip replacement. Upon a single stimulation with the cytokines, the signaling reached its peak after $72 \mathrm{~h}$. Coincubation with only one-tenth of the amount of rhTGF $\beta_{1}$ completely abrogated the rhBMP-2-induced and rhBMP-7-induced Smad1/5/8 signaling in these cells. The opposite is seen in vivo in adult (rodent) kidney, where BMP-7 is expressed and can, when administered exogenously, reduce TGF $\beta$-driven renal fibrogenesis during experimental chronic nephropathies [25]. Expression analysis of the transcription factors (Smad1-5), receptors (Alk1-3, Alk5, Alk6, TGFßRII) and regulatory factors (Smad6, Smad7, Smurf1, Smurf2, SARA, BAMBI, Ski, SnoN, noggin, sclerostin) involved in BMP or TGF $\beta$ signaling, revealed that rhTGF $\beta_{1}$ downregulates the expression of Smad1, Alk1 and TGF $\beta$ RII, both at mRNA and at protein level. This might explain the lack of Smad1/5/8 signaling observed in osteoblasts treated with rhBMP-2 and rhBMP-7 costimulated with rhTGF $\beta_{1}$.
Interestingly, expression of Smad6 was also downregulated by rhTGF $\beta_{1}$, which should enhance Smad1/5/8 signaling by reducing ubiquitination and degradation of Smad1/5/8 and the corresponding receptors by the E3 ubiquitin ligases Smurf1 and Smurf2 [12], where expression in osteoblasts was not affected in our setting. On the contrary, expression of the other inhibitors Smad6 and Smad7 was upregulated. As Smad7 binds to the activated receptors in competition with Smad2/3 [12], and thus serves as a negative feedback regulator for $\mathrm{TGF}_{1}$-dependent Smad2/3 signaling, its induction was not further investigated at this point. Expression levels of the other transcription factors and receptors were not significantly altered in our experimental setup. Similarly, expression levels of the majority of the investigated regulatory factors investigated were not significantly altered in the presence of rhBMP-2, rhBMP-7 or rhTGF $\beta_{1}$, the only exceptions being BAMBI and SnoN. The expression level of SnoN was strongly increased in the presence of $\operatorname{rhTGF} \beta_{1}$. SnoN interferes with TGF $\beta$ signaling by interacting directly with Smad3 [26]. Furthermore, SnoN is reported to antagonize TGF $\beta$ signaling on the transcriptional level via recruitment 


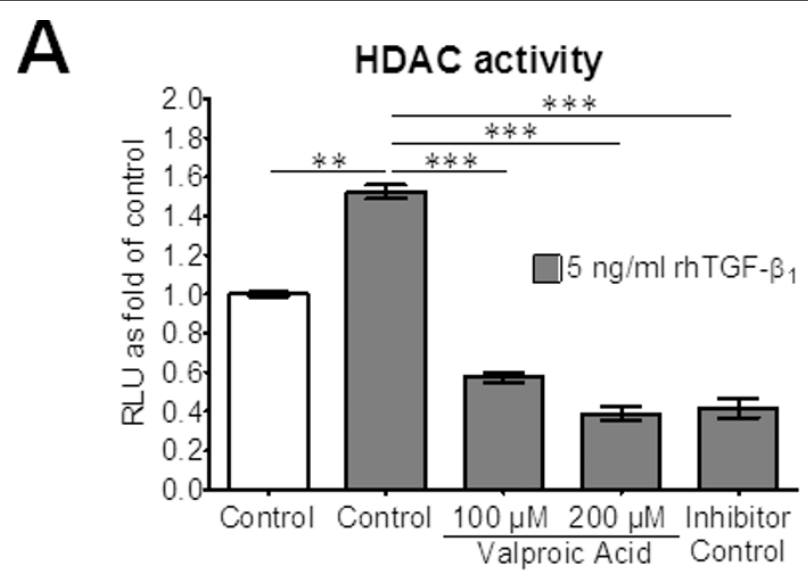

B

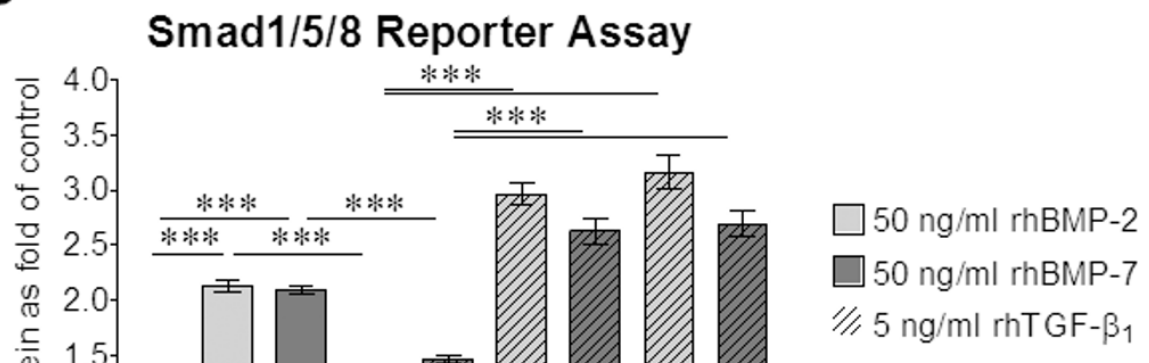

Figure 4 Blocking increased histone deacetylase (HDAC) activity in recombinant human transforming growth factor $\beta_{1}$ (rhTGF $\beta_{1}$ )treated primary human osteoblasts neutralizes the inhibitory effect of rhTGF $\beta 1$ on recombinant human bone morphogenic protein (rhBMP)-2 and rhBMP-7 signaling. (A) HDAC activity in primary human osteoblasts ( $\mathrm{N}=4, \mathrm{n}=3$ ) treated with $5 \mathrm{ng} / \mathrm{ml}$ rhTGF $\beta_{1}$ (gray bars) for $72 \mathrm{~h}$. In order to inhibit HDAC activity lysates were coincubated with two subtoxic doses (100 $\mu \mathrm{M}$ and $200 \mu \mathrm{M})$ of valproic acid. Trichostatin A, provided with the kit used, was used as inhibitor control. (B) Primary human osteoblasts $(\mathrm{N}=4)$ infected with Ad5-BRE-Luc adenoviral particles (Smad1/5/8 reporter construct) were stimulated with $50 \mathrm{ng} / \mathrm{ml}$ rhBMP-2 (light grey bars) or rhBMP-7 (dark gray bars) $\pm 5 \mathrm{ng} / \mathrm{ml} \mathrm{rhTGF} \beta_{1}$ (hatched bars) and $100 \mu \mathrm{M}$ or $200 \mu \mathrm{M}$ HDAC inhibitor (valproic acid) for $72 \mathrm{~h}$. Luciferase activity was measured in cell lysates. The single dose of rhBMP-2 or rhBMP-7 induced Smad1/5/8 signaling, which was completely blocked by rhTGF $\beta_{1}$. Blocking HDAC activity with valproic acid abolished the $\mathrm{rhTGF}_{1}$-dependent inhibition of rhBMP-2 and rhBMP-7 induced Smad1/5/8 signaling. ${ }^{*} P<0.01 ;{ }^{* *} P<0.001$.

of HDACs [12]. Consequently, we demonstrated increased general HDAC activity in rhTGF $\beta_{1}$-treated human osteoblasts, which might be responsible for the observed decreased expression levels of Smad1, Smad6, Alk1 and TGFßRII. HDAC activity was effectively blocked by the administration of two subtoxic doses $(100 \mu \mathrm{M}$ and 200 $\mu \mathrm{M})$ of valproic acid. Blocking HDAC activity by valproic acid was able to abolish the rhTGF $\beta_{1}$-dependent inhibition of rhBMP-2-induced and rhBMP-7-induced Smad1/5/8 signaling in our setup. However, valproic acid does have severe side effects, thus detailed characterization of the specific HDACs regulated by TGF $\beta$ could identify a more specific HDAC inhibitor for use in patients with less side effects. Interestingly, BAMBI expression levels were slightly downregulated in the presence of rhTGF $\beta_{1}$ in our system. This should enhance rhBMP-2 and rhBMP-7 signaling as BAMBI, similar to noggin or sclerostin, has been reported to negatively affect bone formation in vivo by directly interfering with ligand-receptor binding, thus inhibiting both BMP and TGF $\beta$ receptor binding [27,28]. In contrast to that, SnoN affects both TGF $\beta$ and BMP signaling via transcriptional regulation. This points towards a possible novel mechanism how rhBMP-2 and rhBMP-7 fracture therapies in patients could be optimized. Valproic acid is already in clinical use as one of the most common antiepileptic drugs with proposed off-label use as 


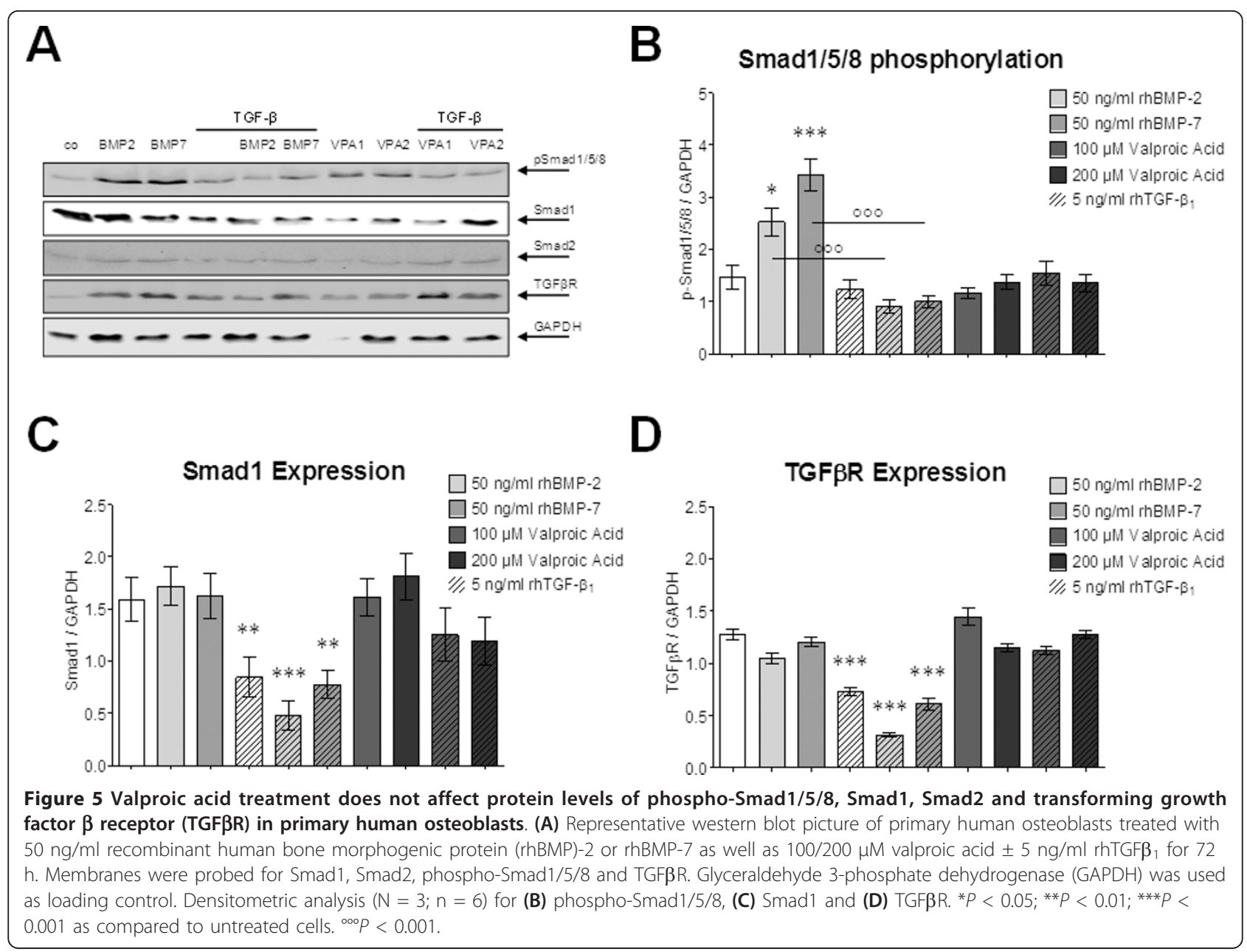

anticancer drug $[29,30]$. However, it still lacks evaluation in vivo as valproic acid is reported to have severe side effects, for example, embryotoxicity. By identification of the specific HDACs regulated by TGF $\beta$, an alternative HDAC inhibitor with fewer side effects could be chosen. Furthermore, as this study focused on primary human osteoblasts as the major target for BMP therapy, the effects of the chosen HDAC inhibitor on bone resorption by osteoclasts should be also investigated. The latter in particularly is limiting for the present study set, since little is known of how HDAC inhibitors may interact with osteoclasts or with a corresponding coculture system. Despite the overall positive results on the use of rhBMP-2 or rhBMP-7 on bone as an adjunct or as a replacement for autograft in compromised patients [2-7], several adverse events, for example, infections, hardware failure, pain, donor site morbidity, heterotopic bone formation and immunogenic reactions, have been reported nonetheless $[8,9]$. In the present experiments addition of valproic acid not only abolished the inhibitory effect of $\operatorname{rhTGF} \beta_{1}$ on rhBMP-2 and rhBMP-7 signaling, but even increased Smad1/5/8 signaling. This is supported by the findings of
Schroeder and Westendorf that show that application of HDAC inhibitors, trichostatin A, sodium burtyrate, valproic acid and MS-275 favors osteoblasts maturation in MC3T3-E1 cells by upregulation of RUNX2 [31]. Interestingly, patients with epilepsy show an increased fracture risk. Thus, it has be extensively studied how antiepileptic drugs affect bone turnover; however, no correlation between valproate medication and loss in bone mineral density was observed [32,33]. This favors the use of this drug for improving BMP therapy. However, it should be further investigated in which way the drug should be administered for improving BMP therapy. An oral application may have advantages for the clinicians to treat patients that already show BMP therapy failure without an additional operation. However, oral administration of valproate may hold the risk for more side effects from the drug per se. This could be limited by a local application of the drug in combination with the BMP itself. Also, to further minimize possible adverse effects by the applied drug it should be further clarified which HDACs are involved in the observed gene regulation to possibly choose a more selective inhibitor with fewer side effects. 


\section{Conclusions}

Based on our data a more general use of valproic acid as an adjunct for rhBMP-2 or rhBMP-7 might be feasible in order to generally increase the efficiency of rhBMPs in vivo and thus, reduce therapeutic costs, making the therapy available for a broader range of patients.

\section{Acknowledgements \\ The work was partially supported by the BBraun foundation.}

\section{Author details}

'BG Trauma Center, Eberhard Karls Universität Tübingen, Schnarrenbergstr. 95, D-72076, Tübingen, Germany. 'Department of Traumatology, MRI, Technische Universität München, Ismaninger Str. 22, D-81675 München, Germany. ${ }^{3}$ Department Nephrology, Klinikum Traunstein, Kliniken Südostbayern AG, Cuno-Niggl-Str. 3, D-83278 Traunstein, Germany. ${ }^{4}$ Department of Medicine II, University Hospital Mannheim, Ruprecht-KarlsUniversität Heidelberg, Theodor-Kutzer-Ufer 1-3, D-68175 Mannheim, Germany. ${ }^{5}$ Department of Oro- and Maxillofacial Surgery, MRI, Technische Universität München, Str. 22, D-81675 München, Germany. ${ }^{6}$ Department of Orthopaedic Surgery, OCM-Clinic Munich, Steinerstr. 6, D-81368 München, Germany.

\section{Authors' contributions}

$\mathrm{SE}, \mathrm{SP}, \mathrm{TF}, \mathrm{AKN}$ and $\mathrm{RH}$ made substantial contributions to conception and design. SE and JZ made substantial contributions to acquisition of data. SE, JZ, SP, TF and AKN performed analysis and interpretation of data. SE, AKN and $\mathrm{RH}$ were involved in drafting the manuscript. JZ, SP, TF, SD and US critically revised the manuscript and provided important intellectual input. All authors gave final approval to the version to be published.

\section{Competing interests}

The authors declare that they have no competing interests.

Received: 7 March 2012 Accepted: 7 September 2012 Published: 7 September 2012

\section{References}

1. Reddi $\mathrm{AH}$ : Role of morphogenetic proteins in skeletal tissue engineering and regeneration. Nat Biotechnol 1998, 16:247-252.

2. Baskin DS, Ryan P, Sonntag V, Westmark R, Widmayer MA: A prospective, randomized, controlled cervical fusion study using recombinant human bone morphogenetic protein-2 with the CORNERSTONE-SR allograft ring and the ATLANTIS anterior cervical plate. Spine (Phila Pa 1976) 2003, 28:1219-1224.

3. Burkus JK, Gornet MF, Schuler TC, Kleeman TJ, Zdeblick TA: Six-year outcomes of anterior lumbar interbody arthrodesis with use of interbody fusion cages and recombinant human bone morphogenetic protein-2. J Bone Joint Surg Am 2009, 91:1181-1189.

4. Geibel PT, Boyd DL, Slabisak V: The use of recombinant human bone morphogenic protein in posterior interbody fusions of the lumbar spine: a clinical series. J Spinal Disord Tech 2009, 22:315-320.

5. Vaccaro AR, Lawrence JP, Patel T, Katz LD, Anderson DG, Fischgrund JS, Krop J, Fehlings MG, Wong D: The safety and efficacy of OP-1 (rhBMP-7) as a replacement for iliac crest autograft in posterolateral lumbar arthrodesis: a long-term (> 4 years) pivotal study. Spine (Phila Pa 1976) 2008, 33:2850-2862.

6. White AP, Vaccaro AR, Hall JA, Whang PG, Friel BC, McKee MD: Clinical applications of BMP-7/OP-1 in fractures, nonunions and spinal fusion. Int Orthop 2007, 31:735-741.

7. Wu LD, Xiong Y, Yu HC: Effects of rhBMP-2 on cortical strut allograft healing to the femur in revision total hip arthroplasties: an experimental study. Int Orthop 2007, 31:605-611.

8. Leach J, Bittar RG: BMP-7 (OP-1) safety in anterior cervical fusion surgery. J Clin Neurosci 2009, 16:1417-1420.

9. Shimer AL, Oner FC, Vaccaro AR: Spinal reconstruction and bone morphogenetic proteins: open questions. Injury 2009, 40(Suppl 3):S32-38.
10. Koppel H, Riedl E, Braunagel M, Sauerhoefer S, Ehnert S, Godoy P, Sternik P, Dooley S, Yard BA: L-carnosine inhibits high-glucose-mediated matrix accumulation in human mesangial cells by interfering with TGF-\{beta\} production and signalling. Nephrol Dial Transplant 2011, 26:3852-3858.

11. Bonewald LF, Dallas SL: Role of active and latent transforming growth factor beta in bone formation. J Cell Biochem 1994, 55:350-357.

12. Shi $Y$, Massague J: Mechanisms of TGF-beta signaling from cell membrane to the nucleus. Cell 2003, 113:685-700.

13. Ellies DL, Viviano B, McCarthy J, Rey JP, Itasaki N, Saunders S, Krumlauf R: Bone density ligand, sclerostin, directly interacts with LRP5 but not LRP5G171V to modulate Wnt activity. J Bone Miner Res 2006, 21:1738-1749.

14. Ehnert S, Baur J, Schmitt A, Neumaier M, Lucke M, Dooley S, Vester $H$, Wildemann B, Stockle U, Nussler AK: TGF-beta1 as possible link between loss of bone mineral density and chronic inflammation. PLOS One 2010, 5:e14073.

15. Border WA, Noble NA: Transforming growth factor beta in tissue fibrosis. N Engl J Med 1994, 331:1286-1292.

16. Leask A: TGFbeta, cardiac fibroblasts, and the fibrotic response. Cardiovasc Res 2007, 74:207-212.

17. Lowry $\mathrm{OH}$, Rosebrough NJ, Farr AL, Randall RJ: Protein measurement with the Folin phenol reagent. J Biol Chem 1951, 193:265-275.

18. Geiser AG, Zeng QQ, Sato M, Helvering LM, Hirano T, Turner CH: Decreased bone mass and bone elasticity in mice lacking the transforming growth factor-beta1 gene. Bone 1998, 23:87-93.

19. Joyce ME, Roberts $A B$, Sporn MB, Bolander ME: Transforming growth factor-beta and the initiation of chondrogenesis and osteogenesis in the rat femur. J Cell Biol 1990, 110:2195-2207.

20. Noda M, Camilliere JJ: In vivo stimulation of bone formation by transforming growth factor-beta. Endocrinology 1989, 124:2991-2994.

21. Rosen D, Miller SC, DeLeon E, Thompson AY, Bentz H, Mathews M, Adams S: Systemic administration of recombinant transforming growth factor beta 2 (rTGF-beta 2) stimulates parameters of cancellous bone formation in juvenile and adult rats. Bone 1994, 15:355-359.

22. Erlebacher A, Derynck R: Increased expression of TGF-beta 2 in osteoblasts results in an osteoporosis-like phenotype. J Cell Biol 1996, 132:195-210.

23. Filvaroff E, Erlebacher A, Ye J, Gitelman SE, Lotz J, Heillman M, Derynck R: Inhibition of TGF-beta receptor signaling in osteoblasts leads to decreased bone remodeling and increased trabecular bone mass. Development 1999, 126:4267-4279.

24. Mohammad KS, Chen CG, Balooch G, Stebbins E, McKenna CR, Davis H, Niewolna M, Peng XH, Nguyen DH, lonova-Martin SS, Bracey JW, Hogue WR, Wong DH, Ritchie RO, Suva LJ, Derynck R, Guise TA, Alliston T: Pharmacologic inhibition of the TGF-beta type I receptor kinase has anabolic and anti-catabolic effects on bone. PLoS One 2009, 4:e5275.

25. Wang S, Hirschberg R: Bone morphogenetic protein-7 signals opposing transforming growth factor beta in mesangial cells. J Biol Chem 2004, 279:23200-23206.

26. Mizuide M, Hara T, Furuya T, Takeda M, Kusanagi K, Inada Y, Mori M, Imamura T, Miyazawa K, Miyazono K: Two short segments of Smad3 are important for specific interaction of Smad3 with c-Ski and SnoN. J Biol Chem 2003, 278:531-536.

27. Balemans W, Ebeling M, Patel N, Van Hul E, Olson P, Dioszegi M, Lacza C, Wuyts W, Van Den Ende J, Willems P, Paes-Alves AF, Hill S, Bueno M, Ramos FJ, Tacconi P, Dikkers FG, Stratakis C, Lindpaintner K, Vickery B, Foernzler D, Van Hul W: Increased bone density in sclerosteosis is due to the deficiency of a novel secreted protein (SOST). Hum Mol Genet 2001, 10:537-543.

28. Wu XB, Li Y, Schneider A, Yu W, Rajendren G, lqbal J, Yamamoto M, Alam M, Brunet LJ, Blair HC, Zaidi M, Abe E: Impaired osteoblastic differentiation, reduced bone formation, and severe osteoporosis in noggin-overexpressing mice. J Clin Invest 2003, 112:924-934.

29. Machado MC, Bellodi-Privato M, Kubrusly MS, Molan NA, Tharcisio T Jr, de Oliveira ER, D'Albuquerque LA: Valproic acid inhibits human hepatocellular cancer cells growth in vitro and in vivo. J Exp Ther Oncol 2010, 9:85-92.

30. Ouyang DY, Ji YH, Saltis M, Xu LH, Zhang YT, Zha QB, Cai JY, He XH: Valproic acid synergistically enhances the cytotoxicity of gossypol in DU145 prostate cancer cells: An iTRTAQ-based quantitative proteomic analysis. J Proteomics 2011, 74:2180-2193. 
31. Schroeder TM, Westendorf JJ: Histone deacetylase inhibitors promote osteoblast maturation. J Bone Miner Res 2005, 20:2254-2263.

32. Aksoy A, Sonmez FM, Deger O, Hosver I, Karaguzel G: The effects of antiepileptic drugs on the relationships between leptin levels and bone turnover in prepubertal children with epilepsy. J Pediatr Endocrinol Metab 2011, 24:703-708.

33. Triantafyllou N, Lambrinoudaki I, Armeni E, Evangelopoulos EM, Boufidou F, Antoniou A, Tsivgoulis G: Effect of long-term valproate monotherapy on bone mineral density in adults with epilepsy. J Neurol Sci 2010,

290:131-134.

\section{Pre-publication history}

The pre-publication history for this paper can be accessed here: http://www.biomedcentral.com/1741-7015/10/101/prepub

doi:10.1186/1741-7015-10-101

Cite this article as: Ehnert et al:: Transforming growth factor $\beta_{1}$ inhibits bone morphogenic protein (BMP)-2 and BMP-7 signaling via upregulation of Ski-related novel protein $\mathrm{N}(\mathrm{SnoN})$ : possible mechanism for the failure of BMP therapy? BMC Medicine 2012 10:101.

\section{Submit your next manuscript to BioMed Central} and take full advantage of:

- Convenient online submission

- Thorough peer review

- No space constraints or color figure charges

- Immediate publication on acceptance

- Inclusion in PubMed, CAS, Scopus and Google Scholar

- Research which is freely available for redistribution

Submit your manuscript at www.biomedcentral.com/submit 